\title{
Indicators of Emotional and Behavioral Problems in Adolescents: Evaluation among Multiple Informants ${ }^{1}$
}

\author{
Bruna Mainardi Rosso Borba², Angela Helena Marin² \\ ${ }^{2}$ Universidade do Vale do Rio dos Sinos, São Leopoldo-RS, Brazil
}

\begin{abstract}
The prevalence rates of emotional and behavioral problems in adolescence suggest that their identification through different informants is relevant for the treatment and prevention of clinical conditions. Therefore, the objective of this study was to evaluate the association and agreement pattern regarding the indicators of internalizing and externalizing problems and total problems among adolescents, their families and teachers. Seventy adolescents, 70 family members and 21 teachers, who answered, respectively, the Youth Self Report and the Child Behavior Checklist in their version for parents and teachers participated in this study. There was greater concordance in the evaluation of adolescents and relatives than of teachers and adolescents and lack of agreement between family members and teachers. In addition, adolescents showed more indicators of internalizing problems. Thus, it is confirmed the need to contemplate multiple informants in the evaluation of emotional/behavioral difficulties of adolescents, with a view to its better understanding and detailing.
\end{abstract}

Keywords: mental health, adolescence, behavior disorders

\section{Indicadores de Problemas Emocionais e de Comportamento em Adolescentes: Avaliação entre Múltiplos Informantes}

\begin{abstract}
Resumo: As taxas de prevalência dos problemas emocionais e de comportamento na adolescência sugerem que sua identificação por meio de diferentes informantes é relevante com vistas ao tratamento e prevenção de quadros clínicos. Portanto, este estudo teve como objetivo avaliar a associação e o padrão de concordância quanto aos indicadores de problemas internalizantes, externalizantes e total de problemas entre adolescentes, seus familiares e professores. Participaram 70 adolescentes, 70 familiares e 21 professores que responderam, respectivamente, ao Inventário de Comportamentos Autorreferidos para jovens e ao Inventário dos Comportamentos de Crianças e Adolescentes em sua versão para pais e para professores. Houve maior concordância na avaliação de adolescentes e familiares do que de professores e adolescentes e ausência de concordância entre familiares e professores. Além disso, os adolescentes evidenciaram mais indicadores de problemas internalizantes. Assim, confirma-se a necessidade de contemplar múltiplos informantes na avaliação de dificuldades emocionais/comportamentais de adolescentes, com vistas a sua melhor compreensão e detalhamento.
\end{abstract}

Palavras-chave: saúde mental, adolescência, distúrbios do comportamento

\section{Indicadores de Problemas Emocionales y del Comportamiento en Adolescentes: Evaluación entre Múltiples Informantes}

\begin{abstract}
Resumen: Las tasas de prevalencia de los problemas emocionales y de comportamiento en la adolescencia sugieren que su identificación por medio de diferentes informantes es relevante con vistas al tratamiento y prevención de cuadros clínicos. Por lo tanto, este estudio tuvo como objetivo evaluar la asociación y el patrón de concordancia con relación a los indicadores de problemas internalizantes, externalizantes y total de problemas entre adolescentes, sus familiares y profesores. En este estudio participaron 70 adolescentes, 70 familiares 21 profesores que respondieron, respectivamente, al Inventario de Comportamientos Autorreferidos para Jóvenes y el Inventario de los Comportamientos de Niños y Adolescentes en su versión para padres y para profesores. Se observó una concordancia en la evaluación de adolescentes y familiares que de profesores y adolescentes y ausencia de concordancia entre familiares y profesores. Además, los adolescentes evidenciaron más indicadores de problemas internalizantes. Así, se confirma la necesidad de contemplar múltiples informantes en la evaluación de dificultades emocionales / comportamentales de adolescentes, con miras a su mejor comprensión y detalle.
\end{abstract}

Palabras clave: salud mental, adolescencia, trastornos de la conducta

\footnotetext{
${ }^{1}$ Article derived from the master's dissertation of the first author under the supervision of the second, defended in 2016, in the Graduate Program in Psychology of Universidade do Vale do Rio dos Sinos. Support: Conselho Nacional de Desenvolvimento Científico e Tecnológico (CNPq).
}

Correspondence address: Bruna Mainardi Rosso Borba. Universidade do Vale do Rio dos Sinos. Programa de Pós-Graduação em Psicologia, Av. Unisinos, 950, sala E01-109, São Leopoldo-RS, Brazil. CEP 93.022-000. E-mail: bruna_borba@yahoo.com.br 
Adolescence is a phase marked by two important transitions: the transition from childhood to the beginning of adolescence and the transition from adolescence to adulthood (Rocha, 2012). This stage of life is characterized by physical, psychological and social vulnerability, distancing from the family of origin and greater approximation with the group of equals, and can be considered a period of risk for the development of emotional and behavioral problems (Lubenko \& Sebre, 2010; Wang et al., 2014).

Emotional and behavioral problems are categorized into externalization problems and internalization problems, according to the specificity of their symptoms (Achenbach \& Rescorla, 2001). Externalization problems are related to opposition, aggression, impulsiveness, defiant behavior, and antisocial manifestations such as teasing and quarreling. Already the problems of internalization involve depression, anxiety, social withdrawal, somatic complaints, fear, excessive worry, sadness, shyness and insecurity (Achenbach \& Edelbrock, 1979).

Regarding the types of behavior problems most frequent in adolescence, there is no consensus in the literature. While some studies point to internalizing symptoms (Borsa \& Nunes, 2011; Liu, Cheng, \& Leung, 2011), others report that externalizing is more prevalent (Alckmin-Carvalho, Izbicki, \& Melo, 2014; Begovac, Rudan, Skocic, Filipovic, \& Szirovicza, 2004). However, it is known that both behaviors affect the psychic development of adolescents, besides being predictors of problems in adult life (Ferdinand, van der Ende, \& Verhulst, 2007; Rocha, 2012).

Studies involving the evaluation of multiple informants on the emotional and behavioral problems of adolescents revealed specificities regarding the agreement patterns. Regarding adolescents' perceptions compared to their parents, Rocha, Ferrari and Silvares (2011) verified that parents identified the presence of more emotional and behavioral problems. On the other hand, there are studies that point out that adolescents tend to report more symptoms about themselves than their parents (Begovac et al., 2004; Chen, Ho, Lee, Wu, \& Gau, 2017). Rescorla et al. (2013), for example, compared 27,861 dyads of parents and adolescents in 25 countries, indicating that adolescents reported significantly more internalizing and externalizing problems than their parents in practically all countries except Puerto Rico. In this sense, SalbachAndrae, Lenz and Lehmkuhl (2009) had already indicated that the level of agreement between the reports of parents and adolescents tends to vary from low to moderate. The hypothesis suggested by some researchers regarding this lack of consensus includes conflicting family interactions in adolescence and the consequent lack of family support (Lubenko \& Sebre, 2010; Sabbag \& Bolsoni-Silva, 2015; Toni \& Silvares, 2013).

Among adolescents and teachers, similarly, agreement on the presence of emotional and behavioral problems is also indicated as low to moderate (Grigorenko, Geiser, Slobodskaya, \& Francis, 2010; SalbachAndrae et al., 2009). The Youngstrom, Loeber and
Stouthamer-Loeber (2000), study on the agreement of emotional and behavioral problems in male adolescents found that teachers identified fewer internalizing and externalizing symptoms than adolescents. The study of Alckmin-Carvalho et al. (2014) showed that teachers reported fewer internalizing and more externalizing problems compared to those reported by bullying students.

Finally, in the perception of parents and teachers, Rus, Tomuletiu, Parris, Pennings and Webster (2016), in a study with adolescents from Romania, pointed out that their parents identified more internalizing behaviors, somatic complaints, problems of thought and attention than the teachers of their children. However, the longitudinal study of Ferdinand et al. (2007) showed that parents identified a higher presence of aggressive behavior in adolescents than teachers. Lyra, Assis, Njaine and Pires (2013) concluded that teachers tend to identify more externalizing problems in their students, except those who suffer from psychic suffering, which identify with more internalizing problems. One of the explanations is that externalizing problems often disrupt the school environment and therefore tend to be more perceived by teachers (Pedrini \& Frizzo, 2010).

It is worth noting that the literature has indicated the need for the use of multiple informants in the evaluation of emotional and behavioral problems in order to provide a more detailed picture of these problems in different contexts. And also to guide potentially effective interventions, as well as to minimize the influence of the various expectations and possible biases of researchers (Gomez, Vance, \& Gomez, 2014; Rescorla, 2016), but there is still a lack of studies in the area. In this perspective, family members and teachers, because they belong to important development contexts, such as family and school, are privileged observers of the behavior of children and adolescents (Major \& Seabra-Santos, 2014). With regard to adolescents, the evaluation of their own behaviors can bring relevant contributions to the understanding of the indicators evaluated (Grigorenko et al., 2010). However, nationally, few studies have been found that have used different sources of information to assess behavioral problems in adolescents (AlckminCarvalho et al., 2014), perhaps due to the difficulty of accessing different informants to evaluate the same case in a period.

In this sense, the objective of this study was to evaluate the association and the agreement pattern regarding the indicators of internalizing and externalizing problems and total problems among adolescents who are attending the final years of elementary school, their families and teachers. It was also sought to verify the association and the pattern of agreement regarding the indicators of anxiety/depression, isolation/depression, somatic complaints, social problems, problems of thought, attention problems, deviant behavior, and aggressive behavior, perceived by multiple informants. Since current studies have prioritized global analysis that consider only the total scores of internalizing and externalizing problems (Oliveira-Monteiro et al., 2011). 


\section{Method}

\section{Participants}

This study is characterized as having a cross-sectional design of the comparative type (Gil, 2008), with a quantitative approach. The sample consisted of 161 participants, of whom 70 were adolescents, coming from two public schools located in a lower-middle class neighborhood in the city of Porto Alegre (Ferreira \& Menezes, 2017), and in their families, represented by the main caregivers, and 21 teachers, who evaluated the corresponding number of students included in this study. The adolescents were aged between 11 and 17 years $(M=12.90, S D=1.08), 41(58.6 \%)$ being female and $29(41.4 \%)$ male. With regard to their schooling, 18 (25.7\%) were in the sixth grade and $52(74.3 \%)$ were in the seventh year of elementary school.

The families were represented by the main caregiver and consisted of $58(82.9 \%)$ biological mothers, six (8.6\%) biological parents, three (4.3\%) foster mothers, one adoptive parent $(1.4 \%)$, one maternal aunt (1.4\%) and a maternal grandmother (1.4\%). Among the teachers, five (23.81\%) were male and $16(76.19 \%)$ female, who ministered to different curricular subjects and had contact with the students at least six months prior to the research. The sample was accessed for convenience and estimated according to the criteria proposed by Hair, Black, Babin, Anderson and Tatham (2009) for analysis of variance, which consider that the minimum required size is 20 subjects in each group for this type of analysis.

\section{Instruments}

Three of the instruments that make up the Achenbach System of Empirically Based Assessment - ASEBA) were used, with versions for different informants, which are presented below. The chosen instruments are well referenced in the world literature, due to the methodological rigor of their elaboration, and are among the most used for characterization of child and adolescent behavior problems (Achenbach \& Rescorla, 2001).

Youth Self Report - YSR (Achenbach \& Rescorla, 2001). It evaluates the mental health of adolescents between the ages of 11 and 18 and is divided into two parts. The first one is composed of items destined to the evaluation of the competences of adolescents. The second, refers to the evaluation of self-reported indicators of emotional and behavioral problems from eight scales that compose three general indices: problems of internalization (anxiety/ depression, isolation/depression and somatic complaints), and total problems, which encompasses all items of behavior problems, in addition to social problems, problems of thought and attention problems. For the purpose of the present study, only this second part of the instrument was used. In relation to the psychometric properties of the instrument, Bordin et al. (2013) revealed that the average test-retest reliability was 0.82 and the internal consistency of the problem scales as measured by Cronbach's alpha ranged from 0.67 to 0.95 . The YSR is in the validation process for the Brazilian population and adequate indices of internal consistency have already been indicated, with the RMSEA index of 0.03, indicating good adjustment (Rocha, 2012).

Child Behavior Checklist - CBCL (Achenbach \& Rescorla, 2001). It assess social competence and the presence of emotional and behavioral problems in children and adolescents according to the perception of parents/ caregivers. As for YSR, only the second part of the inventory was used. Although there is no validation of the instrument for the Brazilian population, Rocha et al. (2013) reported the validity of the factorial structure of the instrument $($ RMSEA $=0.02)$ and its discriminative capacity $(p<001)$. Also, Silvares, Rocha and Emerich (2016) revealed that in the Brazilian version, good internal consistency rates were found for a non-referral sample for mental health services $(\alpha=0.95)$ and for another sample of children and adolescents referred for care in a psychology service in Porto Alegre $(\alpha=0.95)$.

Child and Adolescent Behavior Checklist - Teacher's Report Form - TRF (Achenbach \& Rescorla, 2001). It evaluates the adaptive functioning, academic performance, internalization problems and externalization problems. The instrument is a parallel measure to the CBCL and must be answered by the teacher who has known the student for at least two months. As mentioned in the instruments presented above, we also used only the second level of the inventory that allows us to examine self-reported indicators of emotional and behavioral problems. Bordin et al. (2013) reported that the instrument in the original version had good test-retest reliability $(0.90)$ and internal consistency, as measured by Cronbach's alpha, ranging from 0.72 to 0.97 . However, the validations of the instrument are being conducted in Brazil by researchers from the Universidade Federal do Estado de São Paulo and Universidade de São Paulo (UNIFESP and USP), comparing the items of the versions translated by the groups of researchers for later analysis and finalization of the Brazilian version.

\section{Procedure}

Data collection. Initially, contact was made face-to-face with the Secretariat of Education of the State of Rio Grande do Sul-RS and two schools in the city of Porto Alegre-RS were selected for convenience, considering the location accessible to the first author of this study, responsible for data collection. The families were contacted through informative lectures, as well as meetings for the quarterly evaluations. Those who agreed to participate signed the Free and Informed Consent Form (FICF), received individually the guidelines regarding the fulfillment of all the questions of the instrument and an envelope containing a Letter of Presentation of the Research, instructions on the procedures to fill out the CBCL and the instrument itself, as well as a second sealed envelope. The deadline for the responsible family members was one week, after which 
they were to send the instruments in a sealed envelope to the school. The adolescents, in turn, were accessed in the classroom, with the proper release of the direction of the school and approval of the teacher responsible for the subject, to sign the Term of Consent and to respond collectively to the YSR. Finally, with the teachers was scheduled a day and time that were available at the school to sign the Free and Informed Consent Form and respond to the TRF. In view of the extension of TRF, the period of beginning of collection (third trimester) and considering that many of the participating adolescents were part of the same class, all the teachers of the final years were invited to participate and those who accepted to be part of the study were individually oriented about who they should consider for evaluation, considering the criterion of knowing it for at least two months, in order not to overload them. Thus, none of them filled more than seven inventories.

Data analysis. The responses of the YSR, CBCL and TRF instruments were analyzed from ASEBA-PC. For the purposes of this study, the scales guided by the criteria of the Diagnostic and Statistical Manual of Mental Disorders (DSM-IV) were not considered. Scale scores were classified as clinical (percentiles over 70), borderline or borderline (percentiles between 65-69) and nonclinical (percentiles below 65), but in this study we chose to include adolescents classified as borderline in the clinical category, as recommended by Achenbach and Rescorla (2001).This classification does not represent a diagnosis, but it aids in the identification of risk factors that would indicate the need for professional help. The $\mathrm{T}$ scores for each subscale and scale of the instruments were also used, as this standardizes the results, with no corresponding number of items interfering (Rocha, 2012).

For descriptive statistics, the absolute $(n)$ and relative (\%), distributions, as well as the measures of central tendency and dispersion (average, median and standard deviation) were used with the Kolmorogov-Smirnov test. Cohen's Kappa coefficient (weighted) was used with the objective of assessing the degree of agreement between the responses of adolescents, family members and teachers, in which the classification of Landis and Koch (1977) was followed. The correlation between the average $\mathrm{T}$ scores obtained from the adolescent responses to the YSR, from the relatives to the CBCL and from the teachers to the TRF was calculated from the Pearson correlation coefficient. For the categorization of the intensity of the correlations, the following parameters were considered: weak $(0.1 /-0.1$ to $0.3 /-0.3)$; moderate $(0.4 /-0.4$ to $0.6 /-0.6)$; strong (0.7/-0.7 to 0.9/-0.9) (Dancey \& Reidy, 2006). Afterwards, the Analysis of Variance (ANOVA) with repeated measures (One Way) and Bonferroni Post hoc were used to compare the $\mathrm{T}$ score averages between the YSR, CBCL and TRF scales. We opted for ANOVA with repeated measures considering that these are paired samples. Finally, the comparison of the classifications of the YSR, CBCL and TRF instruments occurred by the Friedman test. The analysis were performed using the statistical program SPSS 22.0 (Statistical Package for Social Science) and the level of significance was considered $p<0.05$.

\section{Ethical Considerations}

The present study was evaluated and approved by the Comitê de Ética em Pesquisa (Research Ethics Committee) of the Universidade do Vale do Rio dos Sinos-RS, under CAAE 47369215.2.0000.5344. Therefore, it meets all the precepts of ethics in research with human beings.

\section{Results}

Initially, we sought to evaluate the degree of agreement between the multiple informants in relation to the scales of the YSR, CBCL and TRF instruments according to the Kappa coefficient. In general, there was significant agreement between adolescents and teachers at the scales of problems of thought $(p<0.01)$ and deviant behavior $(p<0.01)$. Among adolescents and families there was significant agreement on the anxiety/depression scales $(p<0.04)$, somatic complaints $(p<0.01)$, social problems $(p<0.01)$, problems of thought $(p<0.01)$, attention problems $(p<0.03)$ and externalizing problems $(p<0.22)$. Finally, there were no significant agreement between teachers and family members. Table 1 describes the results of the comparison between the informants.

Table 1

Agreement between Informants

\begin{tabular}{lccccccc}
\hline \multirow{2}{*}{ Scales } & $\begin{array}{c}\text { Adolescents } \\
\text { Vs. Teachers }\end{array}$ & $\begin{array}{c}\text { Adolescents } \\
\text { Vs. Relatives }\end{array}$ & $\begin{array}{c}\text { Relatives } \\
\text { Vs. Teachers }\end{array}$ \\
\cline { 2 - 7 } & Kappa & $p$ & Kappa & $p$ & Kappa & $p$ \\
\hline Anxiety/depression & 0.04 & 0.49 & 0.16 & 0.04 & 0.05 & 0.46 \\
Isolation/depression & 0.05 & 0.57 & 0.12 & 0.22 & 0.15 & 0.08 \\
Somatic complaints & 0.00 & 0.99 & 0.30 & 0.00 & 0.06 & 0.33 \\
Social problems & 0.05 & 0.52 & 0.29 & 0.00 & 0.00 & 0.99 \\
Problems of thought & 0.28 & 0.00 & 0.22 & 0.01 & 0.04 & 0.79 \\
Attention problems & 0.02 & 0.82 & 0.20 & 0.03 & 0.18 & 0.05 \\
Deviant behavior & 0.37 & 0.01 & 0.15 & 0.18 & 0.05 & 0.76 \\
Aggressive Behavior & 0.16 & 0.06 & 0.14 & 0.14 & 0.00 & 0.97 \\
Internalizing problems & 0.08 & 0.29 & 0.15 & 0.09 & 0.15 & 0.07 \\
Externalizing problems & 0.06 & 0.49 & 0.22 & 0.01 & 0.11 & 0.24 \\
\hline Note. Test used: Kappa & & & & & &
\end{tabular}

Note. Test used: Kappa 
From the Pearson correlation coefficient, significant and positive correlations were found between adolescents and teachers for the isolation/depression scales $(r=0.28$; $p<0.01)$, attention problems $(r=0.40 ; p<0.001)$, aggressive behavior $(r=0.34 ; p<0.001)$, deviant behavior $(r=0.41$; $p<0.001)$, internalizing problems $(r=0.24 ; p<0.01)$, externalizing problems $(r=0.36 ; p<0.001)$ and total problems $(r=0.33 ; p<0.001)$. Regarding the evaluation performed by the adolescents and their families, significant and positive correlations were found at all scales. Finally, considering the evaluation of family members and teachers, positive correlations were also found between isolation/depression $(r=0.31 ; p<0.001)$, attention problems $(r=0.29 ; p<0.01)$, deviant behavior $(r=0.26 ; p<0.01)$ and externalizing problems $(r=0.26 ; p<0.01)$, as shown in Table 2 .

Afterwards, Analysis of Variance (ANOVA) with repeated measures (One Way) and Bonferroni Post hoc were performed to compare the T score averages of the YSR, CBCL and TRF scales. It was observed that in the anxiety/depression scale the average of the adolescents was higher when compared to the family and teachers $(p<0.001)$. The same occurred in the scales problems of thought, internalizing problems and total problems. In the social problems scale, a difference was found between the scores of adolescents and teachers, with a higher average of the adolescents $(p<0.001)$, as well as for the scales attention problems $(p<0.01)$ and aggressive behavior $(p=0.01)$. In the somatic complaints dimension, the family and adolescent averages did not diverge, differently from the teachers' score. Table 3 shows the averages of the T score on each of the scales among the informants.
Table 2

Correlation between Informants

Coefficient of correlation $(r)$

Scales

$\begin{array}{ccc}\text { Adolescents } & \text { Adolescents } & \text { Relatives } \\ \text { Vs. } & \text { Vs. } & \text { Vs. } \\ \text { Teachers } & \text { Relatives } & \text { Teachers }\end{array}$

\begin{tabular}{lccc}
\hline Anxiety/depression & 0.14 & $0.27^{*}$ & 0.09 \\
Isolation/depression & $0.28^{*}$ & $0.47^{* *}$ & $0.31^{* *}$ \\
Somatic complaints & 0.18 & $0.48^{* *}$ & 0.11 \\
Social problems & 0.10 & $0.37^{* *}$ & 0.09 \\
Problems of thought & 0.16 & $0.38^{* *}$ & 0.04 \\
Attention problems & $0.40^{* *}$ & $0.53^{* *}$ & $0.29 *$ \\
Deviant behavior & $0.41 * *$ & $0.53 * *$ & $0.26^{*}$ \\
Aggressive Behavior & $0.34 * *$ & $0.51 * *$ & 0.15 \\
Internalizing problems & $0.24 *$ & $0.42^{* *}$ & 0.22 \\
Externalizing problems & $0.36 * *$ & $0.58^{* *}$ & $0.26^{*}$ \\
Total problems & $0.33^{* *}$ & $0.56^{* *}$ & 0.18 \\
\hline
\end{tabular}

Note. Test used: Pearson's Correlation. ${ }^{*} p<0.01 .{ }^{* *} p<0.001$

Table 3

Variance between Informants

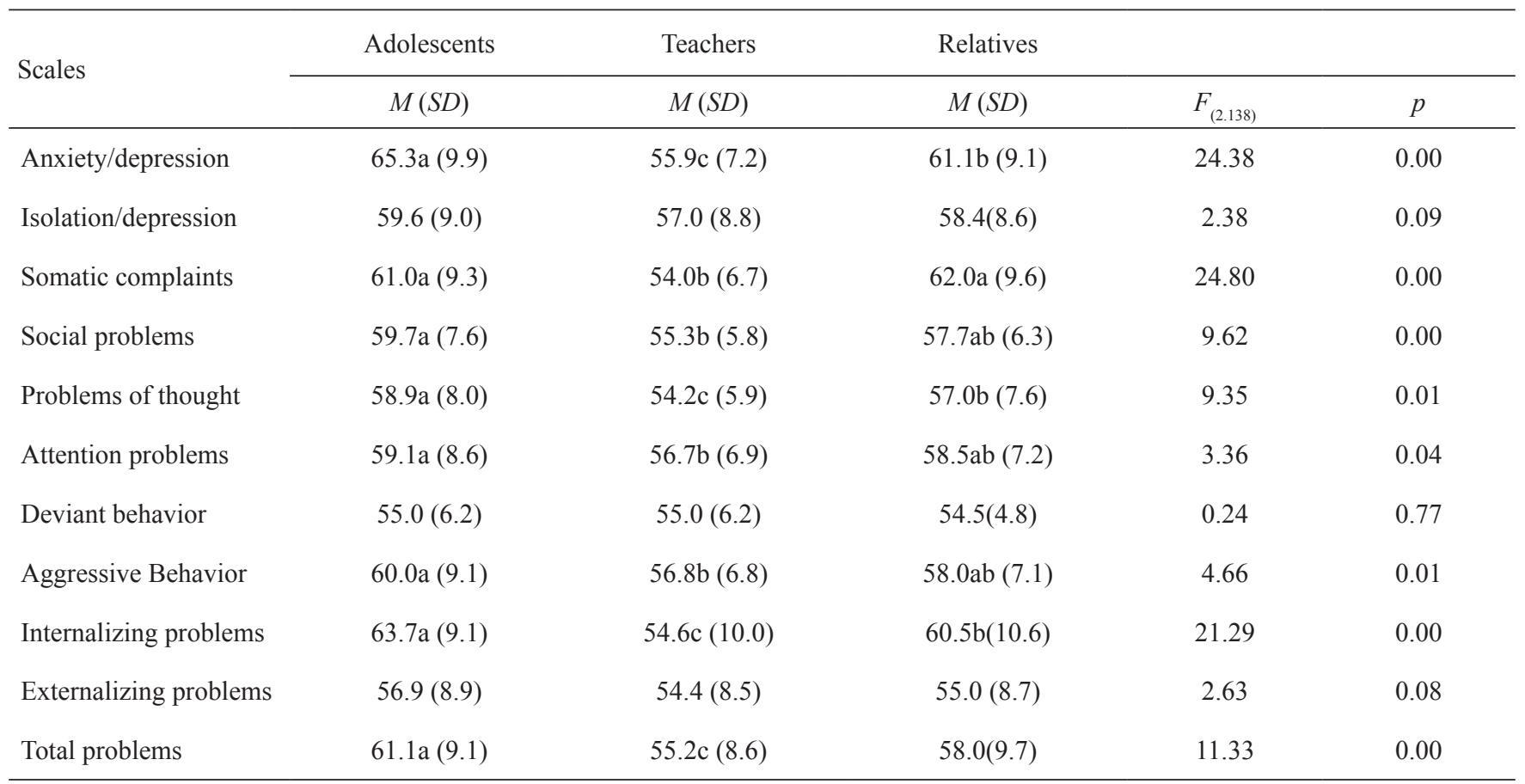

Note. Test used: Analysis of Variance for One-Way Measures - Bonferroni Post Hoc, whose averages followed by equal letters, in the same row, imply statistically similar averages. 
When the scores were classified in clinical and nonclinical, it was observed that in the anxiety and depression scale there was a significant difference $(p<0.01)$ so that the clinical classification was related to $51.5 \%(n=36)$ of the adolescents, $41.1 \%(n=29)$ of the relatives and only $10 \%$ $(n=7)$ of the teachers. Similar results were found on the scale of internalizing problems $(p<0.01)$, in which $62.8 \%$ $(n=44)$ of the adolescents, $57.1 \%(n=40)$ of the relatives and only $28.5 \%(n=20)$ of the teachers classified them as clinicians. Teachers were the ones who classified the students as non-clinical among the scales evaluated. For the isolation/ depression scales, attention problems, deviant behavior, aggressive behavior and externalizing problems, no significant differences were found regarding this classification. Table 4 presents the classification in the clinical and nonclinical categories among the informants (Friedman test).

Table 4

Clinical and Non-clinical Classification by Adolescents, Relatives and Teachers

\begin{tabular}{|c|c|c|c|c|c|c|c|c|c|c|c|c|c|}
\hline \multirow{3}{*}{ Scales } & \multicolumn{4}{|c|}{ Adolescents } & \multicolumn{4}{|c|}{ Teachers } & \multicolumn{4}{|c|}{ Relatives } & \multirow{3}{*}{$p$} \\
\hline & \multicolumn{2}{|c|}{ Non-clinical } & \multicolumn{2}{|c|}{ Clinical } & \multicolumn{2}{|c|}{ Non-clinical } & \multicolumn{2}{|c|}{ Clinical } & \multicolumn{2}{|c|}{ Non-clinical } & \multicolumn{2}{|c|}{$\mathrm{v}$} & \\
\hline & $n$ & $\%$ & $n$ & $\%$ & $n$ & $\%$ & $n$ & $\%$ & $n$ & $\%$ & $n$ & $\%$ & \\
\hline Anxiety / depression & 34 & 48.6 & 36 & 51.5 & 63 & 90.0 & 7 & 10.0 & 41 & 58.6 & 29 & 41.4 & 0.00 \\
\hline Isolation/depression & 51 & 72.9 & 19 & 27.1 & 63 & 90.0 & 7 & 10.0 & 56 & 80.0 & 14 & 20.0 & 0.24 \\
\hline Somatic complaints & 51 & 72.9 & 19 & 27.1 & 65 & 92.9 & 5 & 7.10 & 46 & 65.7 & 24 & 34.3 & 0.01 \\
\hline Social problems & 52 & 74.3 & 18 & 25.7 & 65 & 92.9 & 5 & 7.20 & 60 & 85.7 & 10 & 14.3 & 0.04 \\
\hline Problems of thought & 56 & 80.0 & 14 & 20.0 & 66 & 94.3 & 4 & 5.80 & 55 & 78.6 & 15 & 21.4 & 0.04 \\
\hline Attention problems & 54 & 77.1 & 16 & 22.9 & 60 & 85.7 & 10 & 14.3 & 56 & 80.0 & 14 & 20.0 & 0.32 \\
\hline Deviant behavior & 63 & 90.0 & 7 & 10.0 & 63 & 90.0 & 7 & 10.0 & 67 & 95.7 & 3 & 4.3 & 0.26 \\
\hline Aggressive Behavior & 47 & 67.1 & 23 & 32.9 & 61 & 87.1 & 9 & 12.9 & 55 & 78.6 & 15 & 21.4 & 0.12 \\
\hline Internalizing problems & 26 & 37.1 & 44 & 62.8 & 50 & 71.4 & 20 & 28.5 & 30 & 42.9 & 40 & 57.1 & 0.00 \\
\hline Externalizing problems & 46 & 65.7 & 24 & 34.3 & 51 & 72.9 & 19 & 27.2 & 45 & 64.3 & 25 & 35.7 & 0.18 \\
\hline
\end{tabular}

Note. Test used: Friedman Test

\section{Discussion}

The objective of this study was to evaluate the agreement between adolescents, family members and teachers regarding the emotional and behavioral problems of adolescents who are attending the final years of elementary school, as well as the indicators of internalizing, externalizing problems and total problems pointed out by the different informants. It was observed a greater concordance in the evaluation of relatives and adolescents than teachers and adolescents, corroborating findings of the literature on the subject (Grigorenko et al., 2010; Salbach-Andrae et al., 2009). As for family members and teachers, there was no agreement, which corroborates the results found in other studies (Ferdinand et al., 2007; Lyra et al., 2013; Rus et al., 2016).

In the national context, the final years of elementary school, unlike the initial years, have a differentiated structure and curriculum, requiring the adaptation of both adolescents, who know a new way of relating to various teachers and school contents, and the teachers who need and prepare students for this new form of organization (Arelaro,
Jacomini, \& Klein, 2011). Relatives, in turn, end up having less access to teachers, because they are several and available at different times, which tends to reinforce the distance from the school. Thus, it is important to look at the changes between the different years of teaching, as these aspects may affect the behavior of adolescents, besides contributing to the lack of agreement between family and teachers.

It is plausible to assume that, because of the large number of classes with which teachers interact weekly, the externalizing behaviors, because they disturb the classroom context, end up being more evident (Pedrini \& Frizzo, 2010). To remedy such problems, families are called to be more present at school. However, many family members report fearing and omitting such requests because they understand that they most often refer to behavioral problems or school difficulties of adolescents that they cannot manage (Ferdinand et al., 2007). Such aspects end up contributing to the lack of agreement between family members and teachers.

This discussion is corroborated by the results found, since there were weak to moderate correlations between the three informants, with the lowest among family members 
and teachers, with differences especially in the indicators of attention problems and externalizing problems. This data is in line with the literature on the evaluation of multiple informants on the emotional and behavioral problems of adolescents (Grigorenko et al., 2010; Major \& SeabraSantos, 2014; Rus et al., 2016; Salbach-Andrae et al., 2009; Youngstrom et al., 2000).

It is plausible to suppose that such findings reflect the perspective of each informant. The family represents the main agent of socialization during childhood, but in adolescence there tends to be a distancing and external influences, such as the peer group, begin to have a significant impact on the behavior of adolescents (Lubenko \& Sebre, 2010; Toni \& Silvares, 2013). In this perspective, Begovac et al. (2004), in a survey of 611 adolescents, pointed out that this phase is marked by the identification with the peers and the distancing of the family of origin in order for them to experiment in new social and emotional relations. As a result, they tend not to share their problems anymore and to spend less time at home, which makes it difficult for family members to observe their behavior. However, teachers do not have access to information about the adolescent's behavior at home (Grigorenko et al., 2010), as evidenced by the application of the instruments in the present study. As a result, their evaluation ends up being exempt from the understanding of family dynamics, perceiving, in particular, social situations in a structured context, such as, for example, the relationships between classmates and the field trips provided by the school (Major \& Seabra-Santos, 2014).

Regarding the differences found among the informants, it is noted that the adolescents identified more anxiety/ depression, problems of thought, internalizing problems and total problems than their relatives and teachers. The only scale in which family and adolescents did not differ was that of somatic complaints. As for the adolescents and their teachers, the results differed for social problems, attention problems and aggressive behavior, being more referred by adolescents. Such findings corroborate the study by Youngstrom et al. (2000), which indicated that adolescents perceive themselves as having more internalizing and externalizing symptoms than their teachers. It should be pointed out that as the sample considered refers to students who were not in psychological or psychiatric care, the results also confirm that adolescents highlight more behavior problems than their relatives and teachers, unlike those referred to mental health services, whose evaluation of adults is primarily considered (Chen et al., 2017; Rescorla, 2016; Rocha et al., 2011; Wang et al., 2014).

Evaluating the total scores of problems, it is highlighted that the internalizing problems were more indicated than the externalizing ones by the adolescents and their relatives. There are two possible explanations for such findings. The first one points to the fact that the internalizing symptoms, such as anxiety/depression and somatic complaints are less identified by family members and especially by teachers because they are more restricted to the inner world of adolescents (Alckmin-Carvalho et al., 2014; Pedrini \& Frizzo, 2010).
There seems to be a tendency to underestimate the severity of the internalizing problems in the school context, since most students with such indicators tend to draw less attention in the classroom and to be identified as quieter by teachers (Lyra et al., 2013). The second explanation corresponds to the sample of the present study, which has a greater number of girls, for whom there is an indication of a higher incidence of internalizing symptoms when compared to males (Valverde, Vitalle, Sampaio, \& Schoen, 2012).

In view of the foregoing, it is noted that disagreements between adolescents, family members and teachers need to be taken as fact, since the informants considered are inserted in different contexts and cannot be omitted in the interpretation of information when evaluating adolescents for clinical or of research (Gomez et al., 2014; Grigorenko et al., 2010). In addition, studies have pointed out that discrepancies between informants have their value insofar as they indicate looking at the characteristics and demands of each evaluator and should not be understood as a measurement error that requires a methodological resolution (De Los Reyes, Thomas, Goodman, \& Kundey, 2013; Rescorla, 2016). However, there is a need for further research that addresses this issue.

It should be emphasized that the fact that the sample was derived only from public schools located in districts with a socioeconomic deficiency characteristic, and included only the final years of elementary school can be considered a bias, as well as a limitation, of the present study. It is known that, in Brazil, public school students are commonly from lower income families, compared to those who study in private schools (Borsa \& Nunes, 2011). Lower socioeconomic levels have been associated with a higher incidence of emotional and behavioral problems in children and adolescents (Chen et al., 2017), as well as greater discrepancies in family and teacher evaluations (Stone, Speltz, Collett, \& Werler, 2013). In this sense, it is necessary to evaluate the emotional and behavioral problems of adolescents in other contexts and levels of education. In addition, the sample had the participation of only seven fathers in the evaluation of the adolescents and, considering the importance of the father figure in the development of the children, it is suggested to add the paternal evaluation as a family informant. It should be noted that the sample was not selected by randomness, making it important to use larger and representative samples of the target population in future studies, and that the chosen instruments, which are part of the ASEBA System, are still being validated for the Brazilian population, and may present some level of distortion in relation to the interpretation of the results. However, data analysis software was used that has multicultural norms that were constructed to produce the same distributions of the scores for the classification groups considered to soften this limitation. In any case, it should be pointed out that it was not the objective of the present study to evaluate the measurement instruments used since the focus of analysis was clinical rather than methodological.

It is believed that the present study contributes to the reflection about the evaluation of the indicators of emotional and behavioral problems among adolescents that was 
carried out from multiple informants, making possible the understanding of the emotional development of young people to make a decision about the behaviors that can be the target of future actions in the field of prevention and health promotion. Given the lack of agreement between family members and teachers and the fact that there were more indicators of internalizing problems in the evaluation of adolescents than in the evaluation of adults, it is important that researchers and clinicians consider the perception of different informants about the problems emotional and behavioral problems, considering that the behavior of adolescents may vary in consonance with the context in which they are inserted and with whom they interact. It also highlights the need for family and teachers to understand the emotional demands of adolescents by constructing cozy and understanding spaces for the expression of emotions, since neglecting them has been considered an important risk factor in this development phase.

\section{References}

Achenbach, T. M., \& Edelbrock, C. S. (1979). The child behavior profile: II. Boys aged 12-16 and girls aged 6-11 and 12-16. Journal of Consulting and Clinical Psychology, 47(2), 223-233. doi:10.1037/0022-006X.46.3.478

Achenbach, T. M., \& Rescorla, L. A. (2001). Manual for the ASEBA school-age forms, \& profiles. Burlington, VT: University of Vermont, Research Center for Children, Youth, \& Families.

Alckmin-Carvalho, F., Izbicki, S., \& Melo, M. H. S. (2014). Problemas de comportamento segundo vítimas de bullying e seus professores [Behavior problems according to victim of bullying and their teachers]. Estudos e Pesquisas em Psicologia, 14(3), 834-853. Retrieved from http://www.e-publicacoes.uerj.br/index. php/revispsi/article/view/13886/10607

Arelaro, L. R. G., Jacomini, M. A., \& Klein, S. B. (2011). $\mathrm{O}$ ensino fundamental de nove anos e o direito à educação [Nine-year fundamental education and the right to education]. Educação e Pesquisa,37(1), 35-51. doi:10.1590/S1517-97022011000100003

Begovac, I., Rudan, V., Skocic, M., Filipovic, O., \& Szirovicza, L. (2004). Comparison of self-reported and parent-reported emotional and behavioral problems in adolescents from Croatia. Collegium Antropologicum, 28(1), 393-401. Retrieved from: https://hrcak.srce.hr/file/7966

Bordin, I. A., Rocha, M. M., Paula, C. S., Teixeira, M. C. T. V., Achenbach, T. M., Rescorla, L. A., \& Silvares, E. F. M. (2013). Child Behavior Checklist (CBCL), Youth Self-Report (YSR) and Teacher's Report Form (TRF): An overview of the development of the original and Brazilian versions. Cadernos de Saúde Pública, 29(1), 13-28. doi:10.1590/S0102-311X2013000100004
Borsa, J. C., \& Nunes, M. L. T. (2011). Prevalência de problemas de comportamento em uma amostra de crianças em idade escolar da cidade de Porto Alegre [Prevalence of behavior problems in a sample of school age children of Porto Alegre]. Aletheia, (34), 32-46. Retrieved from http://pepsic.bvsalud.org/scielo.php?script $=$ sci arttext\&pid=S1413-03942011000100004

Chen, Y.-Y., Ho, S.-Y., Lee, P.-C., Wu, C.-K., \& Gau, S. S.F. (2017). Parent-child discrepancies in the report of adolescent emotional and behavioral problems in Taiwan. Plos One, 12(6), 1-12. doi:10.1371/journal.pone.0178863

Dancey, C. P., \& Reidy, J. (2006). Estatísticas em matemática para psicologia: Usando SPSS para Windows [Statistics without mathematics to psychology: Using SPSS for Windows] (3rd ed.). Porto Alegre, RS: Artmed.

De Los Reyes, A., Thomas, S. A., Goodman, K. L., \& Kundey, S. M. (2013). Principles underlying the use of multiple informants' reports. Annual Review of Clinical Psychology, 9, 123-149. doi:10.1146/annurev-clinpsy-050212-185617

Ferdinand, R. F., van der Ende, J., \& Verhulst, F. C. (2007). Parent-teacher disagreement regarding psychopathology in children: A risk factor for adverse outcome? Acta Psychiatrica Scandinavica, 115(1), 48-55. doi: 10.1111/j.1600-0447.2006.00843.x

Ferreira, G. S., \& Menezes, D. B. (2017). Relatório de análise socioeconômica da cidade de Porto Alegre [Socioeconomic analysis report of Porto Alegre]. Porto Alegre: FEE - Fundação de Economia e Estatística. Retrieved from https://www.fee.rs.gov.br/wp-content/uploads/20 17/02/20170209relatorio-analise-socioecon0mica-dacidade-de-porto-alegre-12017.pdf

Gil, A. C. (2008). Métodos e técnicas de pesquisa social [Methods and techniques of social research] (6th ed.). São Paulo, SP: Atlas.

Gomez, R., Vance, A., \& Gomez, R. M. (2014). Analysis of the convergent and discriminant validity of the CBCL, TRF, and YSR in a clinic-referred sample. Journal of Abnormal Child Psychology, 42(8), 1413-1425. doi:10.1007/s10802-014-9879-4

Grigorenko, E. L., Geiser, C., Slobodskaya, H. R., \& Francis, D. J. (2010). Cross-informant symptoms from CBCL, TRF, and YSR: Trait and method variance in a normative sample of Russian youths. Psychological Assessment, 22(4), 893-911. doi:10.1037/a0020703

Hair, J. F., Jr., Black, W. C., Babin, B. J., Anderson, R. E., \& Tatham, R. L. (2009). Análise multivariada de dados [Multivariate data analysis] (6th ed.). Porto Alegre, RS: Bookman.

Landis, J. R., \& Koch, G. G. (1977). The measurement of observer agreement for categorical data. Biometrics, 33(1), 159-174.doi:10.2307/2529310 
Liu, J., Cheng, H., \& Leung, P. W. L. (2011). The application of the preschool Child Behavior Checklist and the caregiver-teacher report form to Mainland Chinese children: Syndrome structure, gender differences, country effects, and inter-informant agreement. Journal of Abnormal Child Psychology, 39(2), 251-264. doi:10.1007/s10802-010-9452-8

Lubenko, J., \& Sebre, S. (2010). Longitudinal associations between adolescent behaviour problems and perceived family relationships. Procedia - Social and Behavioral Sciences, 5, 785-790. doi:10.1016/j.sbspro.2010.07.185

Lyra, G. F. D., Assis, S. G., Njaine, K., \& Pires, T. O. (2013). Sofrimento psíquico e trabalho docente: Implicações na detecção de problemas de comportamento em alunos [Psychological distress and teaching - implications for the detection of problem behavior in students]. Estudos e Pesquisas em Psicologia, 13(2), 724-744. Retrieved from http://www.e-publicacoes.uerj.br/index.php/revispsi/ article/view/8433/7328

Major, S., \& Seabra-Santos, M. J. (2014). Pais e/ou professores? Acordo entre informadores na avaliação sócio emocional de pré-escolares [Parents and/or teachers? Inter-ratter agreement on preschoolers socialemotional assessment]. Psicologia: Teoria e Pesquisa, 30(4), 373-383.

Oliveira-Monteiro, N. R., Aznar-Farias, M., Nava, C. A., Nascimento, J. O. G., Montesano, F.T., \& SpadariBratfisch, R. C. (2012). Estresse, competência e problemas psicológicos de adolescentes estudantes [Stress, competence and psychological problems in adolescent students]. Arquivos Brasileiros de Ciências da Saúde, 37(1), 23-29. doi:10.7322/abcs.v37i1.45

Pedrini, J. R., \& Frizzo, G. B. (2010). Avaliação de indicadores de problemas de comportamento infantil relatados por pais e professores [Evaluation of child behavior problems indicators reported by parents and teachers]. Aletheia, (33), 69-83. Retrieved from http://pepsic.bvsalud.org/scielo. php?script=sci_arttext\&pid=S1413-03942010000300007

Rescorla, L. A. (2016). Cross-cultural perspectives on parent-adolescent discrepancies: Existing findings and future directions. Journal of Youth and Adolescence, 45(10), 2185-2196. doi:10.1007/s10964-016-0554-7

Rescorla, L. A., Ginzburg, S., Achenbach, T. M., Ivanova, M. Y., Almqvist, F., Begovac, I., ... Verhulst, F. C. (2013). Cross-informant agreement between parent-reported and adolescent self-reported problems in 25 Societies. Journal of Clinical Child and Adolescent Psychology, 42(2), 262-273. doi:10.1080/15374416.2012.717870

Rocha, M. M. (2012). Evidências de validade do Inventário de Autoavaliação para Adolescentes (YSR/2001) para a população brasileira [Validity of evidence of the SelfAssessment Inventory for Adolescents (YSR/2001) for the Brazilian population] (Doctoral dissertation). Retrieved from http:/www.teses.usp.br/teses/disponiveis/47/47133/ tde-12062012-153735/pt-br.php
Rocha, M. M., Ferrari, R. A., \& Silvares, E. F. M. (2011). Padrões de concordância entre múltiplos informantes na avaliação dos problemas comportamentais de adolescentes: Implicações clínicas [Agreement patterns between multiple informants in adolescents' behavioral assessment: clinical implications]. Estudos e Pesquisas em Psicologia, 11(3), 948-964. Retrieved from http://pepsic.bvsalud.org/scielo. php?script $=$ sci_arttext\&pid=S1808-42812011000300013

Rocha, M. M., Rescorla, L. A., Emerich, D. R., Silvares, E. F. M., Borsa, J. C., Araújo, L. G., Assis, S. G. (2013). Behavioural/emotional problems in Brazilian children: Findings from parents' reports on the Child Behavior Checklist. Epidemiology and Psychiatric Sciences, 22(4), 329-338. doi:10.1017/S2045796012000637

Rus, A.V., Tomuletiu, E.A., Parris, S.R., Pennings, J.S., \& Webster, R. (2016). Comparisons of emotional and behavioral problems reported by parents and teachers in three ethnic groups living in Romania: A pilot study. Revista de Cercetare si Interventie Sociala, 55, 63-79. Retrieved from https:/www.rcis.ro/images/documente/rcis55_05.pdf

Sabbag, G. M., \& Bolsoni-Silva, A. T. (2015). Interações entre mães e adolescentes e os problemas de comportamento [Interaction among mothers and adolescent and behavior problems]. Arquivos Brasileiros de Psicologia, 67(1), 68-83. Retrieved from http://pepsic. bvsalud.org/scielo.php?script $=$ sci_arttext\&pid=S1809_ $52672015000100006 \& \operatorname{lng}=$ pt\&nrm=iso\&tlng=pt

Salbach-Andrae, H., Lenz, K., \& Lehmkuhl, U. (2009). Patterns of agreement among parent, teacher and youth ratings in referred sample. European Psychiatry, 24(5), 345-351. doi:10.1016/j.eurpsy.2008.07.008

Silvares, E. F. M., Rocha, M. M. R., \& Emerich, D. R. (2016). Inventário de Comportamento da Infância e da Adolescência (CBCL), Relatório para Professores (TRF), Inventário de Autoavaliação para Adolescentes (YSR) [Child Behavior Checklist (CBCL), Teacher's Report Form (TRF), Youth Self-Report (YSR)]. In C. Gorenstein, Y. P. Wang, \& I. Hungerbühler (Eds.), Instrumentos de avaliação em saúde mental (pp. 331-336) [Assessment tools in mental health]. Porto Alegre: Editora Artmed.

Stone, S. L., Speltz, M. L., Collett, B., \& Werler, M. M. (2013).Socioeconomic factors in relation to discrepancy in parent versus teacher ratings of child behavior. Journal of Psychopathology and Behavioral Assessment, 35(3), 314-320. doi:10.1007/s10862-013-9348-3

Toni, C. G. S., \& Silvares, E. F. M. (2013). Práticas educativas parentais e comportamentos de saúde e risco na adolescência: Um modelo preditivo [Parental educational practices and protective behaviors and health risk in adolescents: A predictive mode]. Psicologia Argumento, 31(74), 457-471. doi:10.7213/psicol.argum.31.074.ao01

Valverde, B. S. C. L., Vitalle, M. S. S., Sampaio, I. P. C., \& Schoen, T. H. (2012). Survey of behavioral/ emotional problems in an adolescent outpatient service. Paidéia (Ribeirão Preto), 22(53), 315-323. doi: 10.1590/1.982-43272253201303 
Wang, J., Liu, L., Wu, H., Yang, X., Wang, Y., \& Wang, L. (2014). Agreement between parents and adolescents on emotional and behavioral problems and its associated factors among Chinese school adolescents: A cross-sectional study. BMC Psychiatry, 14, 114-128. doi:10.1186/1471-244X-14-114

Youngstrom, E., Loeber, R., \& Stouthamer-Loeber, M. (2000). Patterns and correlates of agreement between parent, teacher, and male adolescent ratings of externalizing and internalizing problems. Journal of Consulting and Clinical Psychology, 68(6), 1038-1050. doi:10.1037/0022-006X.68.6.1038

Bruna Mainardi Rosso Borba holds a M. Sc. From the Universidade do Vale do Rio dos Sinos, São Leopoldo-RS, Brazil.

Angela Helena Marin is a professor of postgraduate and undergraduate programs in psychology at the Universidade do Vale do Rios dos Sinos, São Leopoldo-RS, Brazil.

Received: Aug. 22, 2016

1st Revision: Dec. 23, 2016

2nd Revision: Jun. 26, 2017

3nd Revision: Nov. 05, 2017

Approved: Feb. 08, 2018

How to cite this article:

Borba, B. M. R., \& Marin, A. H. (2018). Indicators of emotional and behavioral problems in adolescents: Evaluation among multiple informants. Paidéia (RibeirãoPreto), 28, e2825. doi:http://dx.doi.org/10.1590/1982-4327e2825 